\title{
THE EFFECT OF CORPORATE SOCIAL RESPONSIBILITY AND BOARD GENDER DIVERSITY ON BANKRUPTCY: EVIDENCE FROM KOREA
}

\author{
Hyun-Jung Nam and Yohan An* \\ Department of Finance and Accounting, College of Business Administration, \\ Tongmyong University, 428, Sinseon-ro, Nam-gu, Busan 48520, Republic of Korea \\ ${ }^{*}$ Corresponding author: accahn@tu.ac.kr
}

Published online: 1 December 2021

To cite this article: Nam, H. -J., \& An, Y. (2021). The effect of corporate social responsibility and board gender diversity on bankruptcy: Evidence from Korea. Asian Academy of Management Journal, 26(2), 53-74. https://doi.org/10.21315/aamj2021.26.2.3

To link to this article: https://doi.org/10.21315/aamj2021.26.2.3

\begin{abstract}
This study investigates whether corporate social responsibility (CSR) activities and board gender diversity affect bankruptcy. The core issue focuses on the moderating effect between CSR activities and board gender diversity on bankruptcy. Using 4,654 firmyear observations from a sample of 581 non-financial firms listed on the Korean Stock Exchange over the period 2009-2017, we employ the fixed effect estimation and two-way fixed effect estimation of panel analysis to control endogenous. We find firms engaging more in CSR activities reduce the level of bankruptcy, but board gender diversity does not reduce the level of bankruptcy due to tiny portion of female director in the boardroom. The moderating effect on the relationship between CSR activities and board gender diversity reduce the level of bankruptcy. This result indicates that the influence of female directors on the boards of Korean listed firms is not yet strong but board gender diversity with good CSR activities positively operate to reduce the level of bankruptcy.
\end{abstract}

Keywords: bankruptcy, board gender diversity, corporate social responsibility, female director, Korea

(C) Asian Academy of Management and Penerbit Universiti Sains Malaysia, 2021. This work is licensed under the terms of the Creative Commons Attribution (CC BY) (http://creativecommons. org/licenses/by/4.0/). 


\section{INTRODUCTION}

The board of directors is an important governance mechanism, and the effectiveness of board of directors (monitors) depends upon specific factors such as qualifications, experience, expertise, and skills (Rezaee, 2004; Habbash, 2016). Rao and Tilt (2016) propose that having diversified directors on the boards tend to improve management monitoring and disclosure practices for various shareholders because it brings along additional and/or wider variety of perspectives and professional expertise. Specifically, female representation in corporate governance (the boards) as board diversity is a significant and important issue for policymakers and regulatory bodies in many countries. For example, Norway mandated its listed firms to adopt $40 \%$ of their boards to be female to promote gender equality in 2003 (Ahern \& Dittmar, 2012). The Security Commission of Malaysia as an emerging country announces to increase female directors on the boards in top 100 firms at least $30 \%$ by 2020 (Khaw \& Liao, 2018). However, female director representation is only $10.3 \%$ across 67 countries (Terjesen et al., 2015). It is not clear whether the existence of female directors is effective for monitoring firms' management.

Corporate social responsibility (CSR) is the activities done by firm to balance economic prosperity, social integrity, and environmental responsibility (Deegan et al., 2002). Anderson (1989) submits that firm now integrates CSR in its business operation and strategy because CSR gives firm great benefits such as increased sales and market share, reduced operational costs, and increased appeal to investors and financial analysts. Thus, CSR increases firm value in terms of its competitiveness, efficiency, and sustainability; limiting the likelihood of a firm falling into financial difficulties (Hoi et al., 2013).

Using a panel data set of the listed firms on the Korean Stock Exchange (KSE), this study investigates whether CSR activities and board gender diversity affect bankruptcy of the firms by expanding previous studies on the composition of the board of directors. Moreover, this study examines the moderating effect between board gender diversity and CSR activities on bankruptcy. The Korean data provide unique features that well suited to examine the board gender diversity. According to The Economist 2018 glass-ceiling index (GCI), Korea is one of the smallest countries that hold female director in the boardroom. Among the members of the Korean board of directors, the proportion of female directors is $1 \%$ and most of them are family members of firm owners or chief executive officer (CEO) herself (Kim et al., 2017).

This study expects to contribute the literature of board gender diversity and CSR. First, the usefulness of board gender diversity makes the ongoing debate 
on the corporate governance practices to reduce bankruptcy. This study provides empirical evidence that the representation of female director as board gender diversity expects to lower the level of bankruptcy under the business environment where men have authority and power over women. Though most of the business environments of emerging countries are strong male dominance, a few research have been studied on the role of female director (Al-Fadli et al., 2019; Khaw \& Liao, 2018; Marzuki et al., 2019). Therefore, our findings contribute to a good example when female plays a role in defending bankruptcy and is expected to recommend implications that Korean policymakers or regulators need to reform corporate governance practices reflecting board gender diversity.

Second, most of the previous studies analyse the impact of enhancing CSR in female supervision on bankruptcy or the effect of female board members on a firm's risk which have not made distinction with CSR activities and board gender diversity. Combining research on CSR activities and board gender diversity, this study offers empirical results on the moderating effect of board gender diversity and CSR activities on firm's bankruptcy.

\section{LITERATURE REVIEW AND HYPOTHESES DEVELOPMENT}

\section{CSR Activities and Bankruptcy}

CSR activities tend to use a risk management strategy that firms enhance their reputation and protect the firms from the risk of adverse sanctions (Godfrey, 2005; Minor \& Morgan, 2011). Many extant studies show a negative relationship between the implementation or disclosure of CSR and bankruptcy (Al-Hadi et al., 2019; Gross, 2009; Lin \& Dong, 2018). Mecaj and Bravo (2014) also find a negative influence of CSR on financial distress. This shows that better and greater levels of CSR implementation and disclosure could mitigate the level of bankruptcy.

Minor and Morgan (2011) and Hoi et al. (2013) propose the emerging view of CSR activities and reporting as an important part of firm's risk management. Based on the risk management theory, a firm that engages in and reports on its CSR activities would serve the interests of its shareholders, which could actively reduce the risk linked with going bankrupt. Godfrey et al. (2009) further expound the risk management approach by stating that society-based CSR activities produces goodwill and moral capital for the firm, which guide the firm against negative events and add economic value to the firm. Credit analysts perceive positive CSR activities to support their rating decisions because the resulting improvements 
in long-term sustainability reduce the probability of default (Attig et al., 2016). El Ghoul et al. (2011) posit that firms with poor CSR activities are linked to high idiosyncratic risk while stronger CSR activities are highly related to lower cost of capital.

As recent studies, such as Al-Hadi et al. (2019) and Cooper and Uzun (2019), find firms with stronger CSR are less likely to become bankrupt than weaker CSR firms since positive CSR activities support their financial activities and help a firm by engaging stakeholders. In addition, firms with a high CSR level have a low financial distress which means that the higher the CSR performance, the lower financial defaults (Boubaker et al., 2020).

In summary, firm that tend towards bankruptcy engages CSR activities to shift risk and balance financial disposition. Firms with high levels of CSR activities and disclosures limit their tendency of bankruptcy using CSR as an effective risk management tool for bankruptcy. We therefore propose first hypothesis as follows:

H1: CSR activities might have a positive effect to reduce bankruptcy.

\section{Board Gender Diversity and Bankruptcy}

Ample previous studies address that female inclusion in firm's board has benefit to improve firm performance, being more responsive to the market, and achieving better corporate governance (Gul et al., 2013; Hutchinson et al., 2015). A United Nations Development Programme (UNDP 2017) study shows that female's active representation in decision-making bodies enhances the outcome of quality governance and limits the level of corruption. Ward and Forker (2017) argue that the presence of female on the board brings better investment opportunities for the firm because female has difference experiences and perspectives compared with men. As an emerging country study, a female director on the board plays an important risk monitoring role, thus reducing fraudulent financial reporting (Marzuki et al., 2019) and firm's risk-taking behaviour (Khaw \& Liao, 2018) for Malaysian listed firms. Jia (2019) also finds a female director on the risk management committee decrease the probability of financial distress risk because female is better at monitoring and reducing firm's excessive risk-taking behaviour using Australian firms' data. Therefore, female representation in board helps to advance decisions for engagement in activities that will balance economic prosperity, social integrity, and environmental responsibility.

Firms with female directors on the boards provide a better working environment for employees (Johnson \& Greening, 1999; Post et al., 2011). Since female 
director tends to be democratic, communication between members of the board is improved (Eagly et al., 2003), and thus decision-making process through the board becomes more robust (Eagly \& Johnson, 1990).

Heterogeneous group boards perform better than boards of the same quality group in an uncertain situation (Nielsen \& Huse, 2010; Van Knippenberg et al., 2004). In firm with high uncertainty, the higher the diversity of the board of directors, the higher the possibility of overcoming uncertainty through competitiveness of knowledge, competence, and information and effective opinion provision. The diversity of boards is well-performed in uncertain situations and female director presents more effective opinions than male director in uncertain situations (Van Knippenberg et al., 2004). Based on the above discussion, the second hypothesis related to gender diversity is proposed as follows:

H2: Female director on the boards might have a positive effect to reduce bankruptcy.

\section{The Moderating Effect of Board Gender Diversity on CSR and Bankruptcy}

There are three major theories to support the link of board gender diversity and CSR: resource dependency theory, agency theory, and stakeholder theory.

According to the resource dependence theory, the function of the board of directors manages CSR issues and responds to society by providing valuable resources such as legality, advice, and counsel (Boyd, 1990). Pfeffer and Salancik (2003) argue that board members provide tangible and intangible assets that are fundamental to a firm's performance and that shape its behaviour and environment. Ferreira (2010) points out that as board members come from different backgrounds with diverse experience and approach problems in different ways, the board accesses new resources, skills, and knowledge that positively affect its advisory role and decision-making process. In a similar finding, Campbell and Mínguez-Vera (2008) note that board diversity gives a firm broader range of knowledge and heterogeneous group tends to analyse decisions more thoroughly than homogeneous group.

Agency theory proposes that shareholders (the principal) delegate a task to the manager (the agent) so that shareholders only partake in the surplus proceeds of the firm (residual claimants) and do not have direct access to its assets (Fama \& Jensen, 1983; Jensen \& Meckling, 1976). Furthermore, shareholders have vote rights during meetings and control rights which help them monitor the management activities (Fama \& Jensen, 1983; Easterbrook \& Fischel, 1996). 
The manager or the board of directors acts as the supervisory management for the shareholders (Eisenhardt, 1989; Fama \& Jensen, 1983). To carry out this oversight function, the board of directors must have the right mix of knowledge and capacity to appraise management and assess business strategies and their impact on CSR (Hillman \& Dalziel, 2003). In addition, gender composition (number of women on the board) is seen to positively influence social capital and CSR activities. Women on the board bring along different managerial qualities that help decision making, as women are more participative, democratic, and communal (friendly and emotionally expressive) than men (Eagly et al., 2003; Eagly \& Johnson, 1990). The integration of women's unique qualities helps the board effectively improve the firm's CSR adoption and engagement.

Stakeholder theory proposes that manager is tasked with harmonising the legitimate interest of the primary stakeholders. This approach holds that the board of directors represents not only the interests of shareholders but also those of customers, suppliers, employees, and other parties that "matter to the firm" (Finegold et al., 2007). These stakeholders can have wider expectations - firm value, CSR activities, firm sustainability, and gender equity - than just financial concerns. Therefore, the composition of the board should be adjusted to reflect the expectations of all stakeholders (Huse \& Rindova, 2001). Since female directors are more concerned with social and environmental issues than male directors, it is important to appoint female directors to increase firm performance in this area, which is well received among stakeholders (Bear et al., 2010; Branco \& Rodriguez, 2008). Ultimately, this will spur these stakeholders to grant access to the resources they control with definite beneficial effect on firm value and performance.

Female directors on the boards in Korean firms pay more attention to CSRrelevant matter due to more positive attitudes toward the ethics code (Hyun et al., 2016) and the existence of female directors on the board is positively associated with CSR activities in Jordan firms (Al-Fadli et al., 2019). Thus, the presence of female directors on the board might prove to stakeholders that the firm pays attention to women and minorities and thus increases CSR activities.

Consequently, because female pay more attention to CSR activities due to the ethical nature of female, boards with female directors tend to deal more effectively with CSR activities. Considering these reasons, we formulate third hypothesis as follows:

H3: The moderating effect between CSR and female director on the boards might strengthen a positive effect to reduce bankruptcy. 


\section{MATERIALS AND METHODOLOGY}

\section{Sampling Selection and Composition}

The research period of this study is nine years from 2009 to 2017 and the sample includes 4,654 firm-year observations from 581 firms. The study is conducted on listed non-financial firms in the KSE. To identify the data on the gender diversity of board of directors, we collect all corporate governance data including the board of directors provided by TS2000 warehouse database provided by the Korea Listed Firms Association. The CSR data use the Korean Economic Justice Institute (KEJI) index provided by the Economic Justice Research Institute of Korea. All financial data are retrieved from FnGuide database, which is a comprehensive dataset including the information of Korean firm's financial statement and stock exchange. Table 1 presents the sample selection criteria.

Table 1

Sample selection procedure and final sample size

\begin{tabular}{lc}
\hline Summary of sample selection criteria & \\
\hline Criteria: Descriptions & Number of firm-year \\
\hline Firm listed on the KSE & 772 \\
Less: Financial institution (e.g., SIC 65, 66, and 67) & 103 \\
Less: Delisted firms & 56 \\
Less: Firms with missing and outlier data & 32 \\
\hline Total sample firms & 581 \\
\hline
\end{tabular}

\section{Empirical Model}

Since this study uses unbalanced panel data set, we employ the fixed effect estimation of panel analysis to examine the effects of board gender diversity on the relationship between CSR activities and bankruptcy. Unobserved heteroscedasticity should be considered in the process of estimating the impact of female directors on bankruptcy. In this study, since female directors may have heteroscedasticity problems that can be affected by the effect of time-invariant characteristics, the estimates may be limited. For example, it is necessary to eliminate endogenous problems that may arise when a firm's philosophy, culture, or technology development issues are correlated with other entities. By removing these unobserved variables, the net effect of the independent and dependent variables can be found. In addition, when firm fixed effect or year fixed effect is considered to estimate unobserved heteroscedasticity in the relationship between bankruptcy and the director of business, endogenous 
control is possible. Therefore, we use fixed effect estimation to solve the sample selection bias problem and heteroscedasticity problems.

In this study, Model 1 is presented to examine the relationship between CSR activities and bankruptcy, and Model 2 and Model 3 are employed to test the relationship between female director and bankruptcy as well as the moderating effects between CSR activities and female director to bankruptcy. We examine the moderating effect of board gender diversity on bankruptcy panel analysis through a three-step verification process consisting of Model 1, Model 2, and Model 3. In order to examine the moderating effect of board gender diversity, we conduct the three-step regression test of Sharma et al. (1981).

Bankruptcy $=\alpha+\beta_{1} \mathrm{CSR}+\sum_{i=2}^{N} \beta_{i} X_{i, t}+e_{i, t}$

Model (1)

Bankruptcy $=\alpha+\beta_{1} \mathrm{CSR}+\beta_{2}$ Gender $+\sum_{i=3}^{N} \beta_{i} X_{i, t}+e_{i, t}$

Model (2)

Bankruptcy $=\alpha+\beta_{1} \mathrm{CSR}+\beta_{2} \mathrm{CSR} *$ Gender $+\sum_{i=3}^{N} \beta_{i} X_{i, t}+e_{i, t}$

Model (3)

Where, subscripts $i$ denotes the target firm and $t$ is the time period.

The model of this study uses the bankruptcy model proposed by Altman et al. (1977) to select the variables that affect bankruptcy. The bankruptcy is measured by the Altman's Z-score and the CSR variable uses the KEJI index. The board gender diversity is measured by the dummy variable as the presence of female in the board of directors. In addition, we employ five control variables (the $X$ vectors) affecting the bankruptcy and CSR activities of the firm: (1) firm size, (2) leverage ratio, (3) return on assets (ROA), (4) liquidity ratio, and (5) firm with net profit loss.

\section{Measure of bankruptcy}

We use Altman's Z-score (Altman et al., 1977) as a proxy of bankruptcy as the dependent variable in this study. The Altman's Z-score is calculated as follows:

$$
\begin{aligned}
& \mathrm{Z}-\text { score }=1.2 \times \frac{\text { Working Capital }}{\text { Total Assets }}+1.4 \times \frac{\text { Retained Earnings }}{\text { Total Assets }} \\
& \text { Earnings before Market Value of } \\
& +3.3 \times \frac{\text { Interest and Taxes }}{\text { Total Assets }}+0.6 \times \frac{\text { Equity }}{\text { Book Value of }}+0.99 \times \frac{\text { Sales }}{\text { Total Assets }} \\
& \text { Equity }
\end{aligned}
$$


According to Altman's Z-score model, the firm is probably in strong financial health when firm's total score is higher than 2.99 whereas Altman's Z-score lower than 1.81 indicates poor financial health. Thus, the lower the Altman's Z-score, the higher the probability of bankruptcy while the higher the Altman's Z-score, the more financially healthy.

\section{Measure of CSR}

KEJI has reported Korean listed firms' CSR activities using 49 evaluation indicators called as the KEJI index ${ }^{1}$ since 1991. As the representative of CSR index in Korea, many CSR research in Korea used the KEJI index (Nam \& An, 2016). The CSR scores (the percentage of CSR activities) in this study is retrieved from the KEJI. The data provide detailed scores that range from 0 to 100 and through this could identify the level of firms CSR activities.

\section{Measure of board gender diversity}

In order to measure the board gender diversity, we use the existence of female director among the board members following Low et al. (2015) and Conyon and $\mathrm{He}$ (2017). In this study, board gender diversity is measured as dummy variables that takes the value of 1 if a female director exists in the boards and 0 otherwise.

\section{Control variables}

In addition to control the various variables that can affect bankruptcy, it is necessary to control the variable such as firm size (SIZE), leverage ratio (LEV), return on assets $(R O A)$, liquidity ratio $(Q U I C K)$, and firm with net profit loss (LOSS). SIZE is measured as the natural log for total assets to control differences in resourcing, ability to cope with competition, and funding opportunities. Larger firms are likely to be more cautious in risk taking and CSR activities than smaller firms (Liao et al., 2018; Al-Hadi et al., 2019). LEV is measured as shortterm and long-term debt divided by total assets to control the level of a firm's indebtedness because firms with financial distress might have less resources to invest CSR activities (Poletti-Hughes \& Briano-Turrent, 2019). Additionally, we control for firm's profitability using $R O A$ measured as total assets against net income, and the LOSS is measured as 0 if the net profit is negative, 1 otherwise. QUICK is the sum of liabilities divided by the difference between current assets and inventories because of positive association between CSR and liquidity (Subramaniam et al., 2015). 


\section{RESULTS}

\section{Descriptive Statistics and Correlation Analysis}

As reported in Table 2, the basic statistics show that the average level of bankruptcy measured by Altman's Z-score is 3.921, which is higher than 2.99. Overall, Korean listed firms have sound financial status. As a proxy of board gender diversity, the mean value of female director in the boardroom (Gender) is $0.038(3.8 \%)$, suggesting that 178 out of 4,654 observations are female directors. This result shows that the existence of female director in the boardroom is extremely small compared with that of other countries. According to 2017 Gender Diversity Index, female director accounts for $14.5 \%$ and $22.6 \%$ of the boards in North America and in Europe, respectively. Even in Asian region, the percentage of female board members in Asian firms stands at 8\% (The Asian Development Bank, 2016).

Table 2

Descriptive statistics of the variables

\begin{tabular}{lccccc}
\hline Variable & Obs. & Mean & Std. Dev. & Min & Max \\
\hline Bankruptcy & 4,654 & 3.921 & 3.797 & -10.995 & 10.089 \\
Gender & 4,654 & 0.038 & 0.192 & 0 & 1 \\
CSR & 4,654 & 50.167 & 18.335 & 4.1 & 72.5 \\
SIZE & 4,654 & 20.287 & 1.725 & 15.951 & 26.292 \\
LEV & 4,654 & 1.649 & 2.723 & 0.028 & 10.196 \\
ROA & 4,654 & 0.029 & 0.107 & -3.241 & 3.364 \\
QUICK & 4,654 & 0.318 & 0.771 & 0.000 & 29.867 \\
LOSS & 4,654 & 0.193 & 0.395 & 0 & 1 \\
\hline
\end{tabular}

CSR has a mean value of 50.167 with a standard deviation of 18.335. The maximum CSR score in the sample is 72.5 while the minimum CSR score is 4.1 . $C S R^{*}$ Gender as the moderating effect proxy has the mean value of 0.791 with a standard deviation of 6.577. The large standard deviation of CSR can be explained as that the level of CSR activities across Korean firms is very large. The mean value of SIZE is 20.287 with a standard deviation of 1.725 . The mean values of $Q U I C K$ and $R O A$ are relatively low $(0.318$ and 0.329$)$ meaning lower profitability of Korean firms.

Table 3 provides the Pearson correlation between the Altman's Z-score as a substitute variable of bankruptcy and the variables used. The result shows that CSR activities (CSR) and bankruptcy have statistically significant and positive 
correlation (correlations coefficient: $0.050, p<0.015$ ). The board gender diversity (Gender) and bankruptcy have statistically significant and positive correlation (correlation coefficient: $0.035, p<0.005$ ). This is the same result as predicted in the research hypothesis, and the detailed analysis will be given in Table 4, which does not consider various variables affecting the bankruptcy of the firms.

In addition, most of the control variables presented in this study have a statistically significant relationship with bankruptcy. On the other hand, there is no problem of multi-collinearity among independent variables. This suggests an additional proof to robustness of empirical results.

Table 3

Pearson correlation matrix

\begin{tabular}{|c|c|c|c|c|c|c|c|c|c|}
\hline & Bankruptcy & CSR & Gender & $\begin{array}{c}C S R^{*} \\
\text { Gender }\end{array}$ & SIZE & $L E V$ & $R O A$ & QUICK & LOSS \\
\hline Bankruptcy & 1 & & & & & & & & \\
\hline CSR & $\begin{array}{c}0.051 \\
(0.014)\end{array}$ & 1 & & & & & & & \\
\hline Gender & $\begin{array}{c}0.017 \\
(0.183)\end{array}$ & $\begin{array}{c}-0.015 \\
(0.459)\end{array}$ & 1 & & & & & & \\
\hline CSR ${ }^{*}$ Gender & $\begin{array}{c}0.024 \\
(0.059)\end{array}$ & $\begin{array}{c}0.055 \\
(0.008)\end{array}$ & $\begin{array}{c}0.603 \\
(0.000)\end{array}$ & 1 & & & & & \\
\hline SIZE & $\begin{array}{c}-0.049 \\
(0.000)\end{array}$ & $\begin{array}{c}0.030 \\
(0.152)\end{array}$ & $\begin{array}{c}-0.014 \\
(0.285)\end{array}$ & $\begin{array}{c}-0.006 \\
(0.640)\end{array}$ & 1 & & & & \\
\hline$L E V$ & $\begin{array}{c}-0.294 \\
(0.000)\end{array}$ & $\begin{array}{c}-0.053 \\
(0.012)\end{array}$ & $\begin{array}{c}-0.006 \\
(0.673)\end{array}$ & $\begin{array}{c}-0.007 \\
(0.595)\end{array}$ & $\begin{array}{c}0.039 \\
(0.004)\end{array}$ & 1 & & & \\
\hline$R O A$ & $\begin{array}{c}0.356 \\
(0.000)\end{array}$ & $\begin{array}{c}0.029 \\
(0.158)\end{array}$ & $\begin{array}{c}-0.027 \\
(0.034)\end{array}$ & $\begin{array}{c}0.015 \\
(0.236)\end{array}$ & $\begin{array}{c}0.096 \\
(0.000)\end{array}$ & $\begin{array}{c}-0.063 \\
(0.000)\end{array}$ & 1 & & \\
\hline QUICK & $\begin{array}{c}0.210 \\
(0.000)\end{array}$ & $\begin{array}{c}-0.003 \\
(0.899)\end{array}$ & $\begin{array}{c}0.042 \\
(0.001)\end{array}$ & $\begin{array}{c}0.058 \\
(0.000)\end{array}$ & $\begin{array}{c}-0.107 \\
(0.000)\end{array}$ & $\begin{array}{c}-0.032 \\
(0.020)\end{array}$ & $\begin{array}{c}0.020 \\
(0.122)\end{array}$ & 1 & \\
\hline LOSS & $\begin{array}{c}-0.237 \\
(0.000)\end{array}$ & $\begin{array}{c}-0.037 \\
(0.073)\end{array}$ & $\begin{array}{c}0.014 \\
(0.274)\end{array}$ & $\begin{array}{c}-0.035 \\
(0.006)\end{array}$ & $\begin{array}{c}-0.134 \\
(0.000)\end{array}$ & $\begin{array}{c}0.092 \\
(0.000)\end{array}$ & $\begin{array}{c}-0.429 \\
(0.000)\end{array}$ & $\begin{array}{c}-0.017 \\
(0.184)\end{array}$ & 1 \\
\hline
\end{tabular}

Note: ( $p$-value)

\section{Core Results}

\section{CSR and bankruptcy}

Model 1 shows that the coefficient of CSR is positive and statistically significant with the level of bankruptcy at 0.05 levels. If a firm has strong CSR activities, it decreases the level of bankruptcy, while it tends towards bankruptcy or financial 
distress if the firm has low CSR activities. The empirical results in Model 2 and Model 3 also show that CSR are positively significant with bankruptcy, suggesting that an increase in CSR activities by firms could reduce its level of bankruptcy, thus, hypothesis 1 is accepted. The findings support previous studies that increased CSR activities help firms to manage their financial status (Godfrey, 2005). This finding further supports the view that CSR activities preserve firm's financial performance (Godfrey et al., 2009). In addition, this suggests that Korean listed firms have a lot of space for CSR implementation to further improve its financial status, firm value, reputation, and social capital. CSR is the activity engaged by firms to improve financial performance and mitigate bankruptcy by solving social economic prosperity, social equity and environmental issues, raising their value and reputation in public. CSR is social, economic, and environmental activities voluntarily done and practiced beyond making profit and legal responsibilities by firms (Piacentini et al., 2000). A socially responsible firm is return-based investment whose decisions consider all positive and negative economic, social, and environmental effects that may impact its host society. Firms adopting CSR gain increased financial performance, improve their brand image, mitigate risk exposure, and reduce the level of bankruptcy (Lev et al., 2010; Cheng et al., 2014; Strike et al., 2006; Flammer, 2014). Consequently, firms that engage more in positive CSR activities have greater possibility of reducing their level of financial distress (probability of bankruptcy). This finding consistent with Al-Hadi et al. (2019) and Al-Fadli et al. (2019). Namely, the likelihood of bankruptcy (financial distress) are reduced when the level of CSR implementation and activities increase.

\section{Gender diversity and bankruptcy}

The results of Model 2 and Model 3 show that gender is significantly negative at 0.01 levels, which means that female director on the boards has a negative effect on bankruptcy. It suggests that female director on the board does not reduce the level of bankruptcy. For this result, it can be considered as that the proportion of women in the board of directors of listed companies in Korea is remarkably low. In Table 2, the average Gender score is 0.038 , which shows that female director accounts for only $3.8 \%$ of the boardroom. This further suggests that approximately 176 are female out of 4,654 board members used in the study, which shows that most Korean firms do not have female directors in their board. In addition, in a male-dominated board of directors, it may not be easy for female director with different experiences and perspectives to present her opinions or receive support for them. According to Adams et al. (2005) and Terjesen et al. (2009), female directors have a positive effect on CSR and firm reputation; furthermore, a more gender diverse board may also improve a firm's competitive advantage. 
Despite the benefits of board gender diversity, most Korean firms have not taken advantage of this human capital. This suggests that since most Korean firms lack female board directors, they cannot effectively contribute to reducing the probability of bankruptcy. This result presents a different case from most extant studies which suggest that the presence of more female directors increases the board decision making efficiency (Pathan \& Faff, 2013; Kim et al., 2017). Thus, hypothesis 2 is not accepted.

\section{The moderating effect of gender diversity between CSR and bankruptcy}

Female director values CSR more than male (Kolodinsky et al., 2010) and tend to adopt socially responsible activity which develops the society (Pearson, 2007). Setó-Pamies (2015) shows that female responds to environmental related CSR activities. In essence, female is found out to have more responds to CSR activities, thus the moderating effect of female director and CSR should be confirmed. In order to determine the moderating effect of board gender diversity on CSR and bankruptcy, Model 3 is used to test hypothesis 3 using the three-step regression test of Sharma et al. (1981). We find that although Gender is negatively significant, which further confirms a disagreement with hypothesis 2 , the significantly positive value of $C S R^{*}$ Gender in Model 3 suggests that board gender diversity (Gender) has a partial/quasi moderating effect on the relationship between CSR and bankruptcy, and thus hypothesis 3 is accepted. A moderator variable is one which systematically modifies either the form or the strength of the relationship between an independent variable and a dependent variable, thus board gender diversity is partially moderating the relationship between CSR and bankruptcy. This suggests that board gender diversity modifies or strengthens the relationship between CSR and bankruptcy. Consequently, the role of a female director in Korean firms to defend bankruptcy is limited due to small ratio of female director on the boards, but a female director in the firm with good CSR activities effectively reduces the level of bankruptcy even if the ratio of female directors on the board of directors is low.

\section{Robustness test}

Gender diversity is considered as an endogenous variable. Two-way fixed estimation and Generalized Method of Moments (GMM) are widely used to control endogenous of variable. As a robustness test, two-way fixed effect estimation is employed to control the endogenous problem. In addition, we use alternative measurements for board gender diversity proxy as the ratio of female directors to total directors following Nekhili and Gatfaoui (2013) and Miller and Triana (2009). Since two-way fixed effect estimation has the effect of adjusting 
the standard error of the firm year that occurs in the correlation of firms or time, it is considered as a more sophisticated method to control the endogenous generation of the model than fixed effect estimation. Although GMM is a good model for controlling endogenousness, but it is ignoring the unobserved variables. GMM is considered as an inefficient method because in this study unobserved variables consisting of firm-specific invariant characteristics and correlations between variables may incur. Fixed effect estimation and two-way fixed effect estimation are more efficient method to control endogenous problem by considering unobserved variables and remove the error consisting of entities that do not change over time as a parameter. Table 5 presents the results of twoway fixed effect estimation analysis. The impact of board gender diversity both Gender and Gender ratio on bankruptcy is negatively significant at 0.05 levels. Rather, the negative impact of board gender diversity on bankruptcy is reinforced, compared with fixed effect estimation results shown in Table 4 . We also confirm the positive effect of CSR activities on bankruptcy similar with fixed effect estimation result. The moderating effect of board gender diversity between CSR and bankruptcy is constant (Gender) and strengthened (Gender ratio) with the result of fixed effect estimation. Overall, the results of robustness check using two-way fixed effect estimation are highly consistent with the results of fixed effect estimation.

Table 4

Results of fixed effect estimation

\begin{tabular}{|c|c|c|c|}
\hline \multicolumn{4}{|c|}{ Dependent variable: Altman's Z-score } \\
\hline & Model 1 & Model 2 & Model 3 \\
\hline Constant & $\begin{array}{l}26.403^{* * *} \\
(4.50)\end{array}$ & $\begin{array}{l}27.502^{* * *} \\
(4.68)\end{array}$ & $\begin{array}{l}27.416^{* * *} \\
(4.66)\end{array}$ \\
\hline CSR & $\begin{array}{l}0.006^{* *} \\
(1.77)\end{array}$ & $\begin{array}{c}0.006^{*} \\
(1.80)\end{array}$ & $\begin{array}{l}0.005^{* *} \\
(2.33)\end{array}$ \\
\hline Gender & & $\begin{array}{l}-1.240^{* * *} \\
(-2.65)\end{array}$ & $\begin{array}{l}-2.017^{* * *} \\
(-3.07)\end{array}$ \\
\hline CSR*Gender & & & $\begin{array}{l}0.019^{*} \\
(1.90)\end{array}$ \\
\hline SIZE & $\begin{array}{l}-1.118^{* * *} \\
(-3.80)\end{array}$ & $\begin{array}{l}-1.170^{* * *} \\
(-3.98)\end{array}$ & $\begin{array}{l}-0.813^{* * *} \\
(-4.48)\end{array}$ \\
\hline$L E V$ & $\begin{array}{l}-0.048^{* * *} \\
(-14.48)\end{array}$ & $\begin{array}{l}-0.048^{* * *} \\
(-14.51)\end{array}$ & $\begin{array}{l}-0.290^{* * *} \\
(-7.09)\end{array}$ \\
\hline
\end{tabular}

(continued on next page) 
Table 4: (continued)

\begin{tabular}{lccc}
\hline \multicolumn{4}{l}{ Dependent variable: Altman's Z-score } \\
\hline Model 1 & Model 2 & Model 3 \\
\hline ROA & $8.925^{* * *}$ & $8.919^{* * *}$ & $6.685^{* * *}$ \\
& $(15.10)$ & $(15.11)$ & $(6.96)$ \\
QUICK & $0.962^{* * *}$ & $0.962^{* * *}$ & $0.967^{* * *}$ \\
& $(8.02)$ & $(8.03)$ & $(8.07)$ \\
LOSS & -0.390 & $-0.424^{*}$ & $-0.989^{* * *}$ \\
& $(-1.63)$ & $(-1.77)$ & $(-6.48)$ \\
Pr $>$ F & $<0.0001$ & $<0.0001$ & $<0.0001$ \\
Observations & 2251 & 2251 & 2251 \\
$\mathrm{R}^{2}$ & 0.2496 & 0.2527 & 0.2534 \\
Hausman $\left(\chi^{2}\right)$ & 680.8 & 1526.28 & 1602.19 \\
\hline
\end{tabular}

Table 5

Results of two-way fixed effect estimation

\begin{tabular}{lcc}
\hline Dependent variable: Altman's Z-score & \multicolumn{2}{c}{ Two-way fixed effect estimation } \\
\hline \multicolumn{4}{c}{ Constant } & 5.423 & 5.425 \\
& $(1.24)$ & $(1.24)$ \\
CSR & $0.005^{* *}$ & $0.005^{* *}$ \\
& $(2.34)$ & $(2.34)$ \\
Gender & $-2.154^{* * *}$ & \\
& $(-3.06)$ & \\
Gender Ratio & & $-2.161^{* * *}$ \\
& & $(-3.73)$ \\
CSR ${ }^{*}$ Gender & $0.005^{*}$ & \\
CSR ${ }^{*}$ Gender Ratio & $(1.78)$ & \\
& & $0.006^{* *}$ \\
SIZE & & $(1.99)$ \\
& $-0.0435^{* *}$ & $-0.0435^{* *}$ \\
LEV & $(-2.12)$ & $(-2.12)$ \\
& $-0.267^{* * *}$ & $-0.266^{* * *}$ \\
ROA & $(-6.89)$ & $(-6.88)$ \\
& $6.759^{* * *}$ & $6.759^{* * *}$ \\
& $(3.21)$ & $(3.21)$ \\
\hline
\end{tabular}


Table 5: (continued)

\begin{tabular}{lcc}
\hline \multicolumn{2}{l}{ Dependent variable: Altman's Z-score } & \\
\hline \multicolumn{2}{l}{ TwICK } & \multicolumn{2}{l}{ Two-way fixed effect estimation } \\
& $(6.23)$ & $0.765^{* * *}$ \\
LOSS & $-0.981^{* * *}$ & $(6.23)$ \\
& $(-6.42)$ & $-0.981^{* * *}$ \\
Year-fixed dummy & Yes & $(-6.42)$ \\
Pr $>$ F & $<0.0001$ & Yes \\
Observations & 2251 & $<0.0001$ \\
$\mathrm{R}^{2}$ & 0.4527 & 2251 \\
\hline
\end{tabular}

\section{CONCLUSION}

This study examines how CSR activities and female director on the boards affect bankruptcy of the firms. In addition, this study investigates the moderating effect between board gender diversity and CSR on bankruptcy using panel dataset, 4,654 firm-year observations of 581 non-financial listed firms on the KSE for nine years from 2009 to 2017, applying fixed effect estimation and two-way fixed effect estimation method. We find that only $3.8 \%$ of listed Korean firms have female board directors. The proportion of female board directors in Korean firms is very low and remains the lowest among OECD countries compared with other OECD countries including Norway, Sweden, and Australia as well as other emerging countries such as Malaysia and Jordan. These countries have adopted either voluntary or legislative initiatives $(25 \%-50 \%)$ to foster female director on the boards. Our findings suggest that the influence of female directors on the boards of Korean listed firms is not yet strong. CSR activities are positively significant with Altman's Z-score which proves that CSR activities reduce the level of bankruptcy. This further suggests that firms engaging more in CSR activities will reduce the level of bankruptcy. In the analysis of the moderating effect between CSR activities and board gender diversity on bankruptcy, we find the moderating effect between CSR activities and board gender diversity decreases the level of bankruptcy. The findings in our study offer implications that board gender diversity is an important determinant factor of CSR activities and bankruptcy. Although Korean firms have made great efforts to improve their board structure through the introduction of outside and independent board directors and other measures, yet the inclusion of female board director has not been of great concern. Therefore, there is a need for government adoption and implementation of policies and 
measures that will foster the inclusion or introduction of female directors in the board of directors of listed firms in Korea. Given that gender diversity is important to board structure, in the long run, a female director can propose to reduce conflicts with other firms, lower conflicts with suppliers, and ultimately increase CSR activities, therefore defend the level of bankruptcy.

Despite the above findings, we suggest future research directions. The sample of this study is based on the listed firms. In this respect, the lack of sufficient samples can be the limit of the study. Thus, given that analysis of unlisted firms and the additional measure of board gender diversity as another key variable of board structure, future research could present a deep understanding on the effects of diversity on CSR and bankruptcy.

\section{NOTE}

1. The KEJI Index consists of six main categories with 49 evaluation indicators. The six main categories consist of a total score of 100 points: soundness ( 25 points), fairness (20 points), social contribution (15 points), consumer protection (15 points), employee satisfaction (15 points), and environmental management (10 points).

The 49 evaluation indicators are under the six main categories. As the essential evaluation indicators, soundness includes ownership-control disparity, internal ownership ratio, and outside directors on board. Fairness comprises operating audit committee, fair disclosure, and compliance with fair trade laws. Social contribution contains rate of female employment, rate of hiring people with disabilities, and the degree of social welfare support. Consumer protection involves quality and consumer safety and customer satisfaction certification. Employee satisfaction includes ratio of non-regular workers, education and training expenditure per person, and the rate of labour disputes. Environmental management contains environmental investment, operating environmental protection programme, and energy efficiency.

\section{REFERENCES}

Adams, R. B., Haan, J., Terjesen, S., \& Ees, H. (2015). Board diversity: Moving the field forward. Corporate Governance an International Review, 23(2), 77-82. https://doi.org/10.1111/corg.12106

Ahern, K. R., \& Dittmar, A. K. (2012). The changing of the boards: The impact on firm valuation of mandated female board representation. The Quarterly Journal of Economics, 127(1), 137-197. https://doi.org/10.1093/qje/qjr049 
Al-Fadli, A., Sands, J., Jones, G., Beattie, C., \& Pensiero, D. (2019). Board gender diversity and CSR reporting: Evidence from Jordan. Australasian Accounting Business and Finance Journal, 13(3), 29-52. https://doi.org/10.14453/aabfj .v13i3.3

Al-Hadi, A., Chatterjee, B., Yaftian, A., Taylor, G., \& Monzur Hasan, M. (2019). Corporate social responsibility performance, financial distress and firm life cycle: Evidence from Australia. Accounting and Finance, 59(2), 961-989. https://doi.org/10.1111/acfi.12277

Altman, E. I., Haldeman, R. G., \& Narayanan, P. (1977). ZETA analysis: A new model to identify bankruptcy risk of corporations. Journal of Banking and Finance, 1, 29-54. https://doi.org/10.1016/0378-4266(77)90017-6

Anderson Jr, J. W. (1989). Corporate social responsibility: Guidelines for top management. Connecticut: Greenwood Press.

Attig, N., Boubakri, N., El Ghoul, S., \& Guedhami, O. (2016). Firm internationalization and corporate social responsibility. Journal of Business Ethics, 134(2), 171-197. https://doi.org/10.1007/s10551-014-2410-6

Bear, S., Rahman, N., \& Post, C. (2010). The impact of board diversity and gender composition on corporate social responsibility and firm reputation. Journal of Business Ethics, 97(2), 207-221. https://doi.org/10.1007/s10551-010-0505-2

Boubaker, S., Cellier, A., Manita, R., \& Saeed, A. (2020). Does corporate social responsibility reduce financial distress risk? Economic Modelling, 91(Sept), 835-851. https://doi.org/10.1016/j.econmod.2020.05.012

Boyd, B. (1990). Corporate linkages and organizational environment: A test of the resource dependence model. Strategic Management Journal, 11(6), 419-430. https://doi.org/10.1002/smj.4250110602

Branco, M. C., \& Rodrigues, L. L. (2008). Factors influencing social responsibility disclosure by Portuguese companies. Journal of Business Ethics, 83(4), 685-701. https://doi.org/10.1007/s10551-007-9658-z

Campbell, K., \& Mínguez-Vera, A. (2008). Gender diversity in the boardroom and firm financial performance. Journal of Business Ethics, 83(3), 435-451. https://doi.org/10.1007/s10551-007-9630-y

Cheng, B., Ioannou, I., \& Serafeim, G. (2014). Corporate social responsibility and access to finance. Strategic Management Journal, 35(1), 1-23. https://doi.org/10.1002/ smj.2131

Conyon, M. J., \& He, L. (2017). Firm performance and boardroom gender diversity: A quantile regression approach. Journal of Business Research, 79, 198-221. https://doi.org/10.1016/j.jbusres.2017.02.006

Cooper, E., \& Uzun, H. (2019). Corporate social responsibility and bankruptcy. Studies in Economics and Finance, 36(2), 130-153. https://doi.org/10.1108/SEF-01 -2018-0013

Deegan, C., Rankin, M., \& Tobin, J. (2002). An examination of the corporate social and environmental disclosures of BHP from 1983-1997. Accounting, Auditing \& Accountability Journal, 15(3), 312-343. https://doi.org/10.1108/ 09513570210435861 
Eagly, A. H. \& Johnson, B. T. (1990). Gender and leadership style: A meta-analysis. Psychological Bulletin, 108(2), 233-256. https://doi.org/10.1037/0033-2909 .108 .2 .233

Eagly, A. H., Johannesen-Schimidt, M. C., \& van Engen, M. L. (2003). Transformational, transactional and laissez-faire leadership styles: Meta-analysis, Psychological Bulletin, 129(4), 569-591. https://doi.org/10.1037/0033-2909.129.4.569

Easterbrook, F. H., \& Fischel, D. R. (1996). The economic structure of corporate law. Harvard University Press.

Eisenhardt, K. M. (1989). Agency theory: An assessment and review. Academy of Management Review, 14(1), 57-74. https://doi.org/10.5465/amr.1989.4279003 and https://doi.org/10.2307/258191

El Ghoul, S., Guedhami, O., Kwok, C. C., \& Mishra, D. (2011). Does corporate social responsibility affect the cost of capital? Journal of Banking and Finance, 35, 2388-2406. https://doi.org/10.1016/j.jbankfin.2011.02.007

Fama, E. F., \& Jensen, M. C. (1983). Agency problems and residual claims. The Journal of Law and Economics, 26(2), 327-349. https://doi.org/10.1086/467038

Ferreira, D. (2010). Board diversity. Corporate Governance: A Synthesis of Theory, Research, and Practice, 8, 225-242. https://doi.org/10.1002/9781118258439 .ch12

Finegold, D., Benson, G. S., \& Hecht, D. (2007). Corporate boards and company performance: Review of research in light of recent reforms. Corporate Governance: An International Review, 15(5), 865-878. https://doi.org/10.1111/ j.1467-8683.2007.00602.x

Flammer, C. (2014). Does product market competition foster corporate social responsibility? Evidence from trade liberalization. Strategic Management Journal, 36(10), 14691485. https://doi.org/10.1002/smj.2307

Godfrey, P. C., Merrill, C. B., \& Hansen, J. M. (2009). The relationship between corporate social responsibility and shareholder value: An empirical test of the risk management hypothesis. Strategic Management Journal, 30(4), 425-445. https://doi.org/10.1002/smj. 750

Godfrey, P. C. (2005). The relationship between corporate philanthropy and shareholder wealth: A risk management perspective. Academy of Management Review, 30, 777-798. https://doi.org/10.5465/amr.2005.18378878

Gross, A. (2009). Corporate social responsibility and financial distress. ASAC, Niagara Falls. Retrieved from https://www.tias.edu/docs/default-source/ documentlibrary_fsinsight/allen-goss-corporate-financial-responsibility-and -financial-distress.pdf

Gul, F. A., Hutchinson, M., \& Lai, K. M. (2013). Gender-diverse boards and properties of analyst earnings forecasts. Accounting Horizons, 27(3), 511-538. https://doi.org/10.2308/acch-50486

Habbash, M. (2016). Corporate governance and corporate social responsibility disclosure: Evidence from Saudi Arabia. Social Responsibility Journal, 12(4), 740-754. https://doi.org/10.1108/SRJ-07-2015-0088 
Hillman, A. J., \& Dalziel, T. (2003). Boards of directors and firm performance: Integrating agency and resource dependence perspectives. Academy of Management Review, 28(3), 383-396. https://doi.org/10.5465/amr.2003.10196729 and https://doi. org/10.2307/30040728

Hoi, C., Wu, Q., \& Zhang, H. (2013). Is corporate social responsibility (CSR) associated with tax avoidance? Evidence from irresponsible CSR activities. The Accounting Review, 88, 2025-2059. https://doi.org/10.2308/accr-50544

Huse, M., \& Rindova, V. P. (2001). Stakeholders' expectations of board roles: The case of subsidiary boards. Journal of Management and Governance, 5(2), 153-178. https://doi.org/10.1023/A:1013017909067

Hutchinson, M., Mack, J., \& Plastow, K. (2015). Who selects the 'right' directors? An examination of the association between board selection, gender diversity and outcomes. Accounting and Finance, 55(4), 1071-1103. https://doi.org/10.1111/ acfi. 12082

Hyun, E., Yang, D., Jung, H., \& Hong, K. (2016). Women on boards and corporate social responsibility. Sustainability, 8(4), 300. https://doi.org/10.3390/su8040300

Jensen, M. C., \& Meckling, W. H. (1976). Theory of the firm: Managerial behavior, agency costs and ownership structure. Journal of Financial Economics, 3(4), 305-360. https://doi.org/10.1016/0304-405X(76)90026-X

Jia, J. (2019). Does risk management committee gender diversity matter? A financial distress perspective. Managerial Auditing Journal, 34(8), 1050-1072. https://doi.org/10.1108/MAJ-05-2018-1874

Johnson, R. A., \& Greening, D. W. (1999). The effects of corporate governance and institutional ownership types on corporate social performance. The Academy of Management Journal, 42(5), 564-576. https://doi.org/10.5465/256977

Khaw, K., \& Liao, J. (2018). Board gender diversity and its risk monitoring role: Is it significant? Asian Academy of Management Journal of Accounting and Finance, 14(1), 83-106. https://doi.org/10.21315/aamjaf2018.14.1.4

Kim, H. A., Jeong, S. W., Kang, T., \& Lee, D. (2017). Does the presence of female executives curb earnings management? Evidence from Korea. Australian Accounting Review, 27(4), 494-506. https://doi.org/10.1111/auar.12169

Kolodinsky, R. W., Madden, T. M., Zisk, D. S., \& Henkel, E. T. (2010). Attitudes about corporate social responsibility: Business student predictors. Journal of Business Ethics, 91(2), 167-181. https://doi.org/10.1007/s10551-009-0075-3

Lev, B., Petrovits, C., \& Radhakrishnan, S. (2010). Is doing good for you? How corporate charitable contributions enhance revenue growth. Strategic Management Journal, 31(2), 182-200. https://doi.org/10.1002/smj.810

Liao, L., Lin, T. P., \& Zhang, Y. (2018). Corporate board and corporate social responsibility assurance: Evidence from China. Journal of Business Ethics, 150(1), 211-225. https://doi.org/10.1007/s10551-016-3176-9

Lin, K. C., \& Dong, X. (2018). Corporate social responsibility engagement of financially distressed firms and their bankruptcy likelihood. Advances in Accounting, 43, 32-45. https://doi.org/10.1016/j.adiac.2018.08.001 
Low D. C. M., Roberts, H., \& Whiting R. H. (2015). Board gender diversity and firm performance: Empirical evidence from Hong Kong, South Korea, Malaysia and Singapore. Pacific-Basin Finance Journal, 35(1), 381-401. https://doi.org/10.1016/j.pacfin.2015.02.008

Marzuki, M. M., Haji-Abdullah, N. M., Othman, R., Abdul Wahab, E. A., \& Harymawan, I. (2019). Audit committee characteristics, board diversity, and fraudulent financial reporting in Malaysia. Asian Academy of Management Journal, 24(2), 143-167. https://doi.org/10.21315/aamj2019.24.2.7

Mecaj, A., \& Bravo, M. I. G. (2014). CSR actions and financial distress: Do firms change their CSR behavior when signals of financial distress are identified? Modern Economy Scientific Research, 5, 259-271. https://oi.org/10.4236/me.2014.54027

Miller, M., \& Triana, H. (2009). Demographic diversity in the boardroom: Mediators of the board diversity-firm performance relationship. Journal of Management Studies, 46(5), 755-786. https://doi.org/10.1111/j.1467-6486.2009.00839.x

Minor, D. B., \& Morgan, J. (2011). CSR as reputation insurance: Primum non nocere. California Management Review, 53, 40-59. https://doi.org/10.1525/cmr.2011 .53 .3 .40

Nam, H-J., \& An, Y. (2016). Corporate social responsibility and firm value in the Korean shipping logistics industry. Journal of International Trade and Commerce, 12(2), 323-338. https://doi.org/10.16980/jitc.12.2.201604.323

Nekhili, M., \& Gatfaoui, H. (2013). Are demographic attributes and firm characteristics drivers of diversity? Investigating female's positions on French boards of directors. Journal of Business Ethics, 118(2), 227-249. https://doi.org/10.1007/ s10551-012-1576-Z

Nielsen, S., \& Huse, M. (2010). The contribution of female on boards of directors: Going beyond the surface. Corporate Governance an International Review, 18(2), 136148. https://doi.org/10.1111/j.1467-8683.2010.00784.x

Palazzo, G., \& Scherer, A. G. (2008). Corporate social responsibility, democracy, and the politicization of the corporation. Academy of Management Review, 33(3), 773775. https://doi.org/10.5465/amr.2008.32465775

Pathan, S., \& Faff, R. (2013). Does board structure in banks really affect their performance? Journal of Banking and Finance, 37(5), 1573-1589. https://doi.org/10.1016/j. jbankfin.2012.12.016

Pearson, R. (2007). Beyond women workers: Gendering CSR. Third World Quarterly, 28(4), 731-749. https://doi.org/10.1080/01436590701336622

Pfeffer, J., \& Salancik, G. R. (2003). The external control of organizations: A resource dependence perspective. New York: Harper and Row (original work published in 1978).

Piacentini, M., MacFadyen, L., \& Eadie, D. (2000). Corporate social responsibility in food retailing. International Journal of Retail \& Distribution Management, 28(11), 459-469. https://doi.org/10.1108/09590550010356822

Poletti-Hughes, J., \& Briano-Turrent, G. C. (2019). Gender diversity on the board of directors and corporate risk: A behavioural agency theory perspective. International Review of Financial Analysis, 62, 80-90. https://doi.org/10.1016/ j.irfa.2019.02.004 
Post, C., Rahaman, N., \& Rubow, E. (2011). Green governance: Boards of directors' composition and environmental corporate social responsibility. Journal of Business Ethics, 50(1), 189-223. https://doi.org/10.1177/0007650310394642

Rao, K., \& Tilt, C. (2016). Board composition and corporate social responsibility: The role of diversity, gender, strategy and decision making. Journal of Business Ethics, 138(2), 327-347. https://doi.org/10.1007/s10551-015-2613-5

Rezaee, Z. (2004). Corporate governance role in financial reporting. Research in Accounting Regulation, 17, 107-149. https://doi.org/10.1016/S1052-0457(04)17006-9

Setó-Pamies, D. (2015). The relationship between women directors and corporate social responsibility. Corporate Social Responsibility and Environmental Management, 22(6), 334-345. https://doi.org/10.1002/csr.1349

Sharma, S., Durand, R. M., \& Gur-Arie, O. (1981). Identification and analysis of moderator variables. Journal of Marketing Research, 18(3), 291-300. https://doi.org/10.1177/002224378101800303

Strike, V. M., Gao, J., \& Bansal, P. (2006). Being good while being bad: Social responsibility and the international diversification of US firms. Journal of International Business Studies, 37(6), 850-862. https://doi.org/10.1057/palgrave.jibs.8400226

Subramaniam, R. K., Samuel, S. D., \& Mahenthiran, S. (2015). Liquidity implications of corporate social responsibility disclosures: Malaysian evidence. Journal of International Accounting Research, 15(1), 133-153. https://doi.org/10.2308/jiar $-51204$

Terjesen, S., Aguilera, R. V., \& Lorenz, R. (2015). Legislating a woman's seat on the board: Institutional factors driving gender quotas for boards of directors. Journal of Business Ethics, 128(2), 233-251. https://doi.org/10.1007/s10551-014-2083-1

Terjesen, S., Sealy, R., \& Singh, V. (2009). Female directors on corporate boards: A review and research agenda. Corporate Governance an International Review, 17(3) 320-337. https://doi.org/10.1111/j.1467-8683.2009.00742.x

The Asian Development Bank. (2016). Women's leadership and corporate performance. Retrieved from https://www.adb.org/sites/default/files/publication/179587/ewp -472.pdf

The Economist. (2019). The glass ceiling index. Retrieved from https://www.economist .com/graphic-detail/2019/03/08/the-glass-ceiling-index

United Nations Development Program (UNDP). (2017). Human Development Report.

Van Knippenberg, D., De Dreu, C. K., \& Homan, A. C. (2004). Work group diversity and group performance: An integrative model and research agenda. Journal of Applied Psychology, 89(6), 1008-1034. https://doi.org/10.1037/0021-9010.89 .6 .1008

Ward, A. M., \& Forker, J. (2017). Financial management effectiveness and board gender diversity in member-governed, community financial institutions. Journal of Business Ethics, 141(2), 351-366. https://doi.org/10.1007/s10551-015-2699-9 